\title{
The Isolation and Characterization of the Two Macromolecular Antitumor Agents from Streptomyces
}

\author{
By Shigeharu Inouye \\ Research Laboratories of Meiji Seika Kaisha, Ltd., Yokohama \\ Received April 10, 1962
}

\begin{abstract}
Purification of the two antitumor macromolecules, A216 and A280 substances, from culture filtrates of Streptomyces is achieved by chromatography using ion-exchanged celluloses. The purified macromolecules appeared homogeneous are characterized as a protein from the chemical and biological properties by paper clectrophoresis, paper chromatography and ultracentrifuge.

The simple method for approximation of molecular weight of a protein from distribution coefficient on gel filtration is proposed. The molecular weights of both macromolecules given by gel filtration are near to those given by ultracentrifugal analysis.
\end{abstract}

The isolation of antitumor substances of macromolecular nature produced by Streptomyces species have been reported by several workers ${ }^{1 \sim 4}$. Unfortunately, purification of these substances has not been pursued extensively so that none of them has been prepared as a substantially pure macromolecules.

In the course of screening studies of antitumor antibiotics from Streptomyces broths, many macromolecular substances have been isolated in this laboratory, the preliminary chemical and biological studies about these substances were described previously ${ }^{5}$. Since among them A216 and A280 showed high potencies against Ehrlich ascites carcinoma in mice, the further chemical studies about the two substances have been carried on.

1) S. Hosora, Chemotherapy, 3, 128 (1955).

2) Y. Harada, T. Nara and F. Okamoto, J. Antibiotics, Ser. A, 9, 6 (1956).

3) R. Sugawara, A. Matsumae and T. Hata, ibid., Ser. A, 10, 133 (1957).

4) M. Soeda, ibid. Ser. B, 12, 300 (1959); S. Okumura, M. Soeda and H. Sumiyama, Chemotherapy, 8, 373 (1960).

5) Y. Sekizawa, S. Inouye and K. Kagino, J. Antibiotics, Ser. A, in press.
Purification of the Two Macromolecular Antitumor Agents.

A216 was produced by Streptomyces rubrireticuli No. A216. Since it had essentially no activity against a wide variety of microbiological systems in vitro, the isolation and purification of the active principle were followed by tests in vivo on mice. For the preliminary concentration of the active substance from culture filtrate, the precipitation with addition of ammonium sulfate followed by dialysis against dilute hydrochloric acid was used. After concentration of non-dialysable fraction by freeze-drying, the active principle in the concentrated solution was precipitated by adding 5 volumes of ethanol. The crude substance A216 thus obtained was purified by re-precipitation with about 30 $75 \%$ ethanol, then by passing through a column of DEAE-cellulose*1, and finally by chromatographing on a column of CM-cellulose ${ }^{* 2}$. The active fraction eluted with $0.05 \mathrm{M}$

\footnotetext{
*1 Diethylaminoethyl cellulose obtained from California Corporation for Biochemical Research, U.S.A.

*2 Carboxymethyl cellulose obtained from California Corporation for Biochemical Research, U.S.A.
} 
CharT 1. Purification of A216.

A216 Filtered Broth

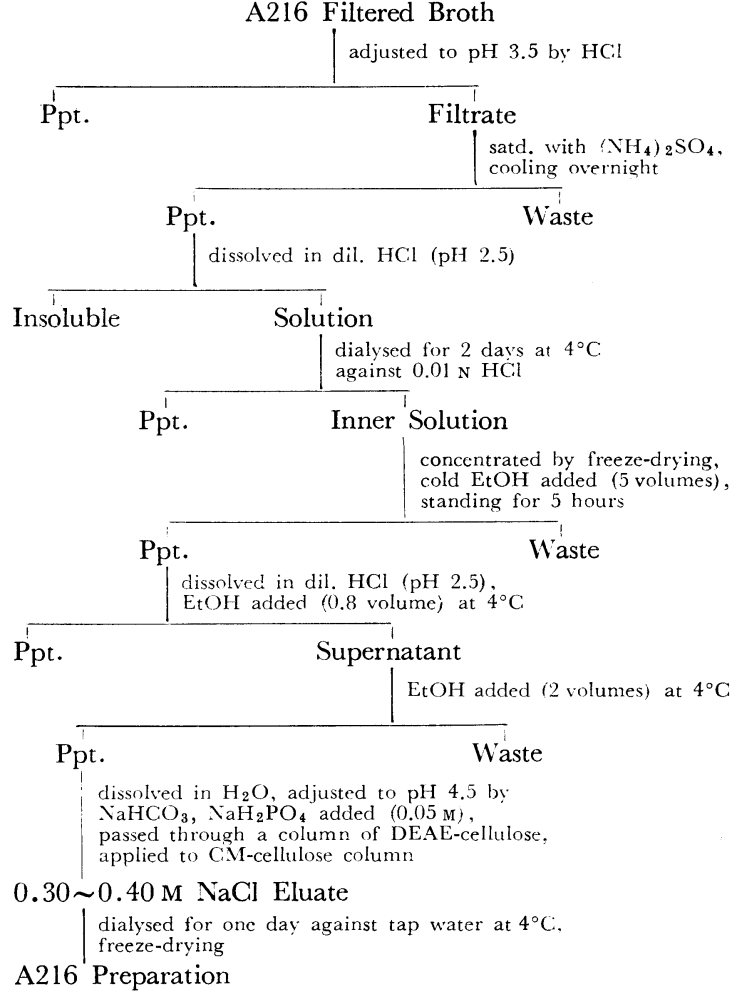

Ghart 2. Isolation Procedure of A280.

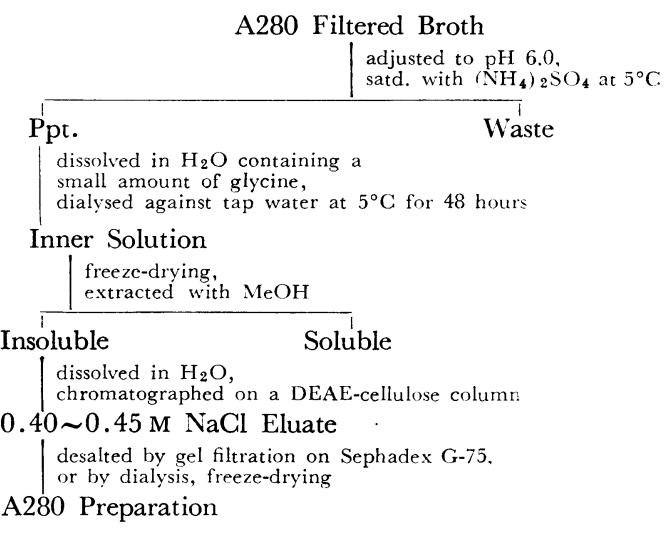

sodium dihydrogen phosphate containing $0.30 \sim 0.40 \mathrm{M}$ sodium chloride from CM-cellulose was desalted by dialysis and freeze-dried. A summary of the purification methods is given in Chart 1 .

In the culture filtrate of Streptomyces species No. A280 were produced substance A280 together with two quinoxaline antibiotics. The isolation procedure of A280 from fermentation broth is shown in Chart 2. The crude A280 preparation was purified by chromatography on DEAE-cellulose instead of CM-cellulose.

Purities and Properties of the Two Macromolecular Antitumor Agents.

A216 is readily soluble in dilute hydrochloric acid, soluble in neutral water and $25 \%$ ethanol, but insoluble in $75 \%$ ethanol, methanol and other organic solvents. It is stable under weak acid condition ( $\mathrm{pH} 2 \sim 3)$, particularly in hydrochloric acid solution, but unstable in alkaline. Most of the activity disappeared when A216 was shaken with organic solvent, such as a mixture of $n$-butanol and chloroform, or digested with pepsin for one day at $37^{\circ} \mathrm{C}$, due to the destruction of native state responsible for the activity.

A216 could be characterized by paper chromatography and paper electrophoresis, by detecting with protein-staining dyes such as Light Green SF, Amide Black 10B, bromophenol blue and Azocarmine G. (Under the same condition, pepsin could be stained well only by Amide Black 10B, but trypsin could not be stained.) In ascending paper chromatography developed with ethanol-0.02 N hydrochloric acid in the ratios of $55: 45$ and 75 : 25 using Toyo Roshi No. 50, A216 gave each single spot at $R_{F} \quad 0.49$ and 0.00 respectively. When paper impregnated with $0.02 \mathrm{~N}$ hydrochloric acid and developed with ethanol$0.02 \mathrm{~N}$ hydrochloric acid $(55: 45), R_{F}$ value was $0.82\left(R_{F}\right.$ Values of pepsin under the same conditions were $0.45,0.00$ and 0.76 respectively). In paper electrophoresis, A216 migrated faster towards cathode than pepsin in glycine-hydrochloric acid buffer at $\mathrm{pH} 2.0$ 
$(\mu=0.1)$. The migrations towards cathode were also observed in both veronal buffer at $\mathrm{pH} 8.6$ and phosphate buffer at $\mathrm{pH} 7.5$, indicating the basic nature of A216 substance.

The ultraviolet absorption spectrum in water was characterized by the weak maxima at $280 \mathrm{~m} \mu\left(\mathrm{E}_{1 \mathrm{~cm}}^{1 \%}=24, \mathrm{pH} 2 \sim 6\right)$ and at $290 \mathrm{~m} \mu$ (pH 12) (Fig. 1), attributable to tyrosine and tryptophan components in A216 substance, showing also the absence of nucleic acid component. The infrared absorption spectrum in potassium bromide pellet indicates the pattern of typical polypeptide, showing absorption at 3435, 3320, 2925, 1650, 1530, 1440 and $1240 \mathrm{~cm}^{-1}$ (Fig. 2) .

Mild acid hydrolysis of A216 by $0.5 \mathrm{~N}$ sul-

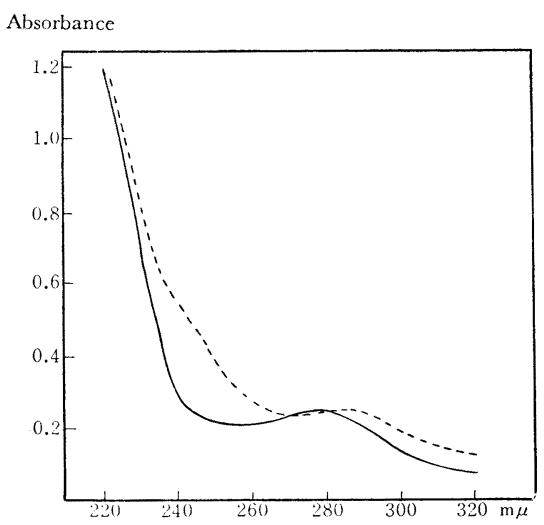

FIG. 1. Ultraviolet Absorption Spectrum of A 216 Substance $\left(\mathrm{H}_{2} \mathrm{O}\right)$.

$\begin{array}{ll}-\cdots-\cdots & \mathrm{pH} 12.0 \\ & \mathrm{pH} 6.0\end{array}$

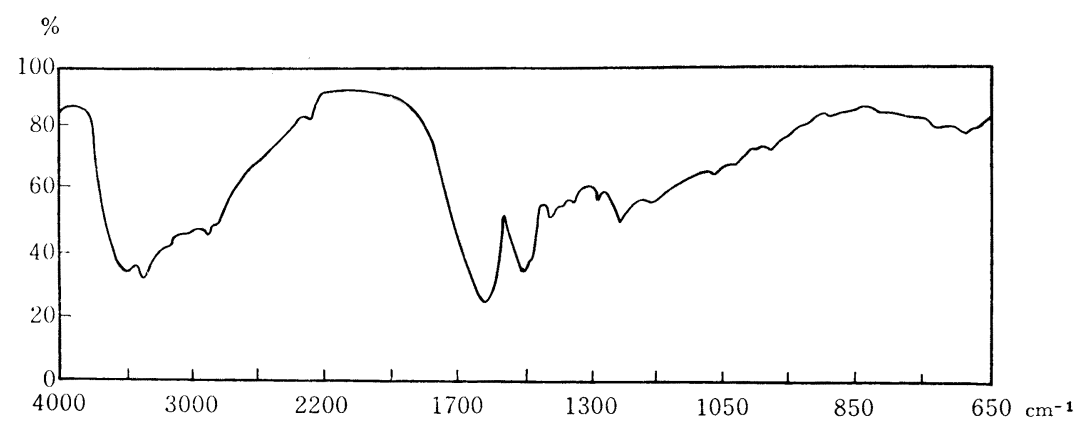

FIG. 2. Infrared Absorption Spectrum of A 216 Substance (KBr). furic acid at $100^{\circ} \mathrm{G}$ for five hours did not afford any ether-soluble material under acid or alkaline condition, and on reducing power appeared, indicating the absence of lipide and carbohydrate components. Analysis of the complete hydrolysate with hydrochloric acid by two dimensional paper chromatography on Toyo Roshi No. 50 paper with the following solvent paires: the first direction, $n$-butanol-acetic acid-water $(4: 1: 2.5)$; and in the second direction, $80 \%$ phenol, disclosed the following amino acids: leucine, phenylalanine, valine, proline, tyrosine, alanine, glycine, threonine, serine, glutamic acid, aspartic acid, cystine, lysine, arginine and histidine. Examination of the hydrolysate by means of ninhydrin and aniline hydrogenphthalate reactions for aminosugar gave negative result. In the alkaline hydrolysate by barium hydroxide, tryptophan was detected.

A280 is soluble in neutral water, but insoluble in acid water, methanol, ethanol, and other organic solvents. It is stable in neutral, moderately stable under acid or alkaline condition. It is precipitated by zinc acetate, lead acetate and acetic acid or other acids, but can not be precipitated by ammonium reineckate, sodium phosphotungstate, sodium trichloroacetate, calcium chloride and sodium picrate. The precipitates produced by addition of zinc acetate or zinc chloride are soluble in aqueous glycine solution. 
A280 differing from A216 is hardly stained with the dyes such as bromophenol blue, Amide Black 10B, Light Green SF, or Azocarmine G. In paper electrophoresis, a single spot of the black A280 substance migrated towards anode, both in veronal buffer at $\mathrm{pH}$ 8.6 and in sodium acetate-acetic acid buffer at $\mathrm{pH}$ 3.86, which suggests the acid nature of A280 substance. In glycine-hydrochloric acid buffer at $\mathrm{pH} 2.47$, no migration was observed. From a companion strip at $\mathrm{pH} 3.86$, the black powder was eluted and found to be biologically active.

The ultraviolet absorption in water is strong, but no absorption maximum appears under acid or alkaline condition (Fig. 3). Infrared absorption spectrum in potassium

Absorbance

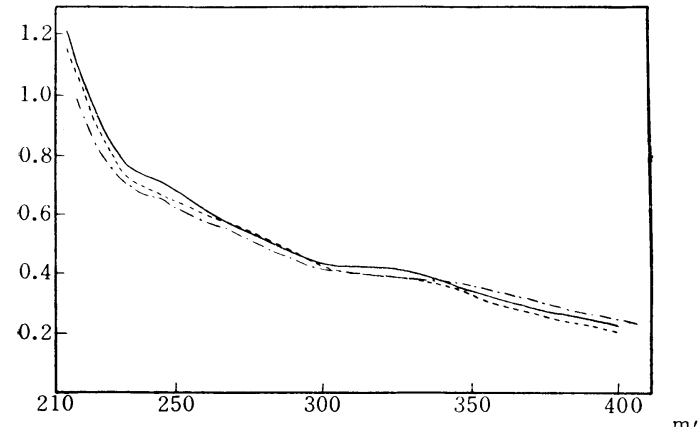

FIG. 3. Ultraviolet Absorption Spectrum of A 280 Substance $\left(\mathrm{H}_{2} \mathrm{O}\right)$.

.-.-... $48 \mu \mathrm{g} / \mathrm{ml} 0.03751 \mathrm{~N} \mathrm{NaOH}$

$-50 \mu \mathrm{g} / \mathrm{ml}$ distil. $1 \mathrm{~N} \mathrm{H}_{2} \mathrm{O}$

$\ldots . . .48 \mu \mathrm{g} / \mathrm{ml} 0.03751 \mathrm{~N} \mathrm{HCl}$ bromide pellet shows maxima attributable mainly to peptide bond and probably to car. bon-oxygen bond (Fig. 4) .

By the mild hydrolysis of A280 either with $1 \mathrm{~N}$ sulfuric acid at $100^{\circ} \mathrm{C}$ for four hours or with $0.5 \mathrm{~N}$ sodium hydroxide at $100^{\circ} \mathrm{C}$ for one hour, no reduced sugar (tested by red tetrazolium and Tollen reagents), and no spectral change in ultraviolet region were observed. A chromogenic substance in the hydrolysates could not be extracted by ethyl ether under acid or alkaline condition. The amino acid components of A280 were examined with the solution hydrolysed by $12 \mathrm{~N}$ hydrochloric acid at $100^{\circ} \mathrm{C}$ for eight hours. By two-dimensional paper chromatography with the same solvent system employed above, 12 amino acids were obtained, i.e., leucine, valine, phenylalanine, proline, alanine, glycine, threonine, serine, glutamic acid, aspartic acid, lysine and histidine, but no aminosugar was found.

Evidently both A216 and A280 substances isolated are proteins. They are non-dialysable and may be fractionated by standard procedures of protein separation. The antitumor activity of A216 is destroyed either upon incubation with pepsin or by bringing into contact with organic solvents, which are characteristic phenomena observed for protein. Both substances are antigenic when injected into mice ${ }^{5)}$. The biological activity of A280 is associated with a single band ob-

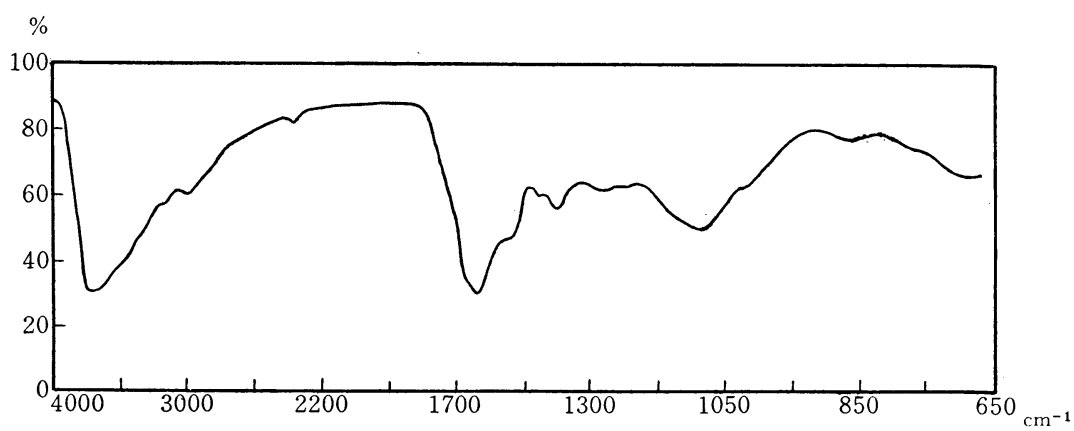

FIG. 4. Infrared Absorption Spectrum of A 280 Substance (KBr). 
tained by paper electrophoresis. The ultraviolet and infrared absorption spectra together with the amino acid components are consistent with this view. The absence of any noticeable amount of lipide, carbohydrate and nucleic acid in both preparations may also be considered as a criterion of purity.

Among the known antitumor substances, none was found to be closely related to A216, indicating to be a new antitumor agent. Though carinomycin ${ }^{1)}$, carzinostatin ${ }^{2)}$ and melanomycin ${ }^{3)}$ have some similarity to A280, they can be distinguished by the amino acid composition, the precipitation behavior, and the microbial activity reported previously5).

\section{Approximation of Molecular Weight by Gel Filtra-} tion.

For the determination of the approximate molecular weights of these two macromolecular antitumor agents, an attempt was first made by utilizing the gel filtration technique, which has been employed for the separation of protein ${ }^{6}$.

A protein submitted to gel filtration with columns of synthetic dextrans of varying cross linkages shows a various degree of retarded passage according primarily to the molecular size, which can be conveniently expressed by $K_{\text {D }}$ value, calculated from the equation shown in experimental part. Since the size of molecule, at least for proteins of similar shape, can often be regarded as proportional to molecular weight, it is anticipative to correlate $K_{\mathrm{D}}$ value with molecular weight*.

Table I shows results for the well characterized proteins whose molecular weights are given, filtered through three different degree of dextran gels (Sephadex G-25, G-50 and G-

6) J. Porath, Biochim. Biophys. Acta, 39, 193 (1960).

* The similar methods for approximation of molecular weight based primarily on the molecular size have been presented by Craig using the free diffusion dialysis (L.C. Craig, "Fractionation and Characterization by Dialysis", A Laboratory Manual of Analytical Methods of Protein Chemistry, Vol. 1, Pergamon Press, 1960, p. 104) and by Pierce and Free using the electrodialysis in starch gels J.C. Pierce and C.A. Free, Biothim. Biophys. Acta, 48, 436 (1961).
TABle I. $K_{D}$ VAlues OF VARIOUS PROTEINS Filtered Through Columns of Sephadex G-25, G-50 AND G-75 WITH 0.05 M PHOSPHATE BUFFER OF $\mathrm{pH} 6.0$ OR WITH DISTILlED WATER AS ELUANT

\begin{tabular}{|c|c|c|c|c|c|}
\hline \multirow[b]{2}{*}{ Protein } & \multirow[b]{2}{*}{$\begin{array}{l}\text { Mol. } \\
\text { Wt. }\end{array}$} & \multicolumn{4}{|c|}{$K_{1)}$ Value } \\
\hline & & $\mathrm{G}-25$ & $\mathrm{G}-50$ & G-75 & $\begin{array}{c}\mathrm{G}-50 \\
\left(\mathrm{H}_{2} \mathrm{O}\right)\end{array}$ \\
\hline Oxytocin & 1,000 & 0.60 & 1.18 & & 1.16 \\
\hline Actinomycin & 1,300 & 0.48 & 1.04 & & 1.04 \\
\hline Bacitracin & 1,400 & 0.41 & 0.99 & & 0.94 \\
\hline Sarmin sulfate & $\begin{array}{r}5,000 \\
10,000\end{array}$ & $\sim_{0.04}$ & 0.40 & 0.70 & 0.86 \\
\hline Gytochrome c & 13,000 & 0.00 & 0.12 & 0.15 & 0.84 \\
\hline Ribonuclease & 13,600 & 0.01 & 0.26 & 0.55 & 0.82 \\
\hline Lysozyme & 14,800 & 0.01 & 0.44 & 0.71 & 0.90 \\
\hline Trypsin & 22,000 & 0.00 & 0.14 & $\begin{array}{c}0.38 \\
(1.04)^{*}\end{array}$ & 0.84 \\
\hline Trypsirogen & 22,000 & 0.00 & 0.12 & 0.34 & 0.80 \\
\hline Pepsin & 35,000 & 0.05 & 0.02 & 0.18 & -0.04 \\
\hline Ovalbumin & 45,000 & -0.01 & 0.04 & 0.165 & 0.04 \\
\hline Serum albumin & 65,000 & -0.02 & 0.02 & 0.05 & \\
\hline Methohemoglobin & 68,000 & 0.00 & 0.02 & 0.18 & 0.82 \\
\hline$\gamma$-Globulin & 150,000 & 0.04 & 0.02 & 0.00 & \\
\hline A216 Substance & $\begin{array}{r}5,000 \\
15,000\end{array}$ & $\sim 0.00$ & 0.38 & 0.56 & 0.86 \\
\hline A280 Substance & $\begin{array}{l}15,000 \\
25,000\end{array}$ & $\sim 0.06$ & 0.12 & 0.43 & 0.06 \\
\hline
\end{tabular}

75 obtained from Pharmacia, Sweden). Apart from the results obtained with distilled water as eluant, an expected relationship between increasing molecular weights and $K_{\mathrm{D}}$ values was shown within the limitation described below. Irregularity was observed in the case of cytochrome c. Ambiguous results obtained with distilled water may be ascribed partly to the different charged protein ions and partly to the dissociation of protein in distilled water ${ }^{7}$. A major limitation in the method to estimate molecular weight from $K_{\mathrm{D}}$ value arises from the lack of dextrans with a series of porosity suitable for general studies. With Sephadex G-25, G-50 and G-75, the approximation will be reasonable for protein

\footnotetext{
7) M. Nagahisa and A. Hattori, cited in " Chemistry of Proteins", Vol. 3, edited by S. Akabori and S. Mizushima, Kyoritsu Shuppan Co., Ltd., 1955, p. 185.
} 
in the molecular weight in range of $3,500 \sim$ 50,000 .

The approximate molecular weights for the two macromolecular antitumor agents, estimated from the $K_{\mathrm{D}}$ values shown in Table I, are 5,000 15,000 for A216 and 15,000 25,000 for A280.

The molecular weights given by gel filtration were traced by ultracentrifugal analysis. In the sedimentation patterns, one symmetrical but diffused peaks were obtained with both substances as shown in Figs. 5 and 6 . Sedimentation constants of A216 and A280 are $1.2 \mathrm{~S}\left(\mathrm{~S}_{17.5, \mathrm{w}}^{\prime}\right)$ and $2.2 \mathrm{~S}\left(\mathrm{~S}_{20, \mathrm{w}}^{\prime}\right)$ respectively. Thus, the molecular weights which would be anticipated from the sedimentation constants $^{8)}$ were near to those suggested by gel filtration. Furthermore, the apparent molecular weight of A216 was determined to be 13,000 by Archibald method modified by Trautman ${ }^{9}$, assuming a partial specific volume of 0.70 .

\section{EXPERIMENTAL*}

\section{Isolation of A 216 Substance.}

The strain of Streptomyces rubrireticuli No. A216 produced at least two bio-active substances, A216 and an antiHeLa cell substance, in the culture filtrate. The latter was isolated using preparative paper chromatography $\left(R_{F} 0.72\right.$; ascending method; filter paper, Toyo Roshi No. 50; development solvent, $n$-butanolacetic acid-water $(4: 1: 2.5 \mathrm{v} / \mathrm{v}))$ and showed no activity in vivo against Ehrlich ascites carcinoma in mice, in spite of the strong activities against HeLa cell in tissue culture and against Ehrlich carcinoma cell in cylinder assay medium.

As A216 showed no effect except for in vivo inhibition against experimental animal tumors, process for the isolation was studied by testing the activity against ascites type of Ehrlich carcinoma in mice.

The filtered broth (190 1) was adjusted to $\mathrm{pH} 3.5$ with $2 \mathrm{~N} \mathrm{HCl}\left(\begin{array}{ll}1.35 & 1\end{array}\right)$ and the solution was kept overnight at $5^{\circ} \mathrm{C}$. To the supernatant obtained by centrifugation, solid ammonium sulfate $(67 \mathrm{~kg})$ was added, and the saturated solution was kept for 24 hours at $5^{\circ} \mathrm{C}$, and the resulting precipitate $(300 \mathrm{~g})$ was collected by centrifugation. The above precipi-
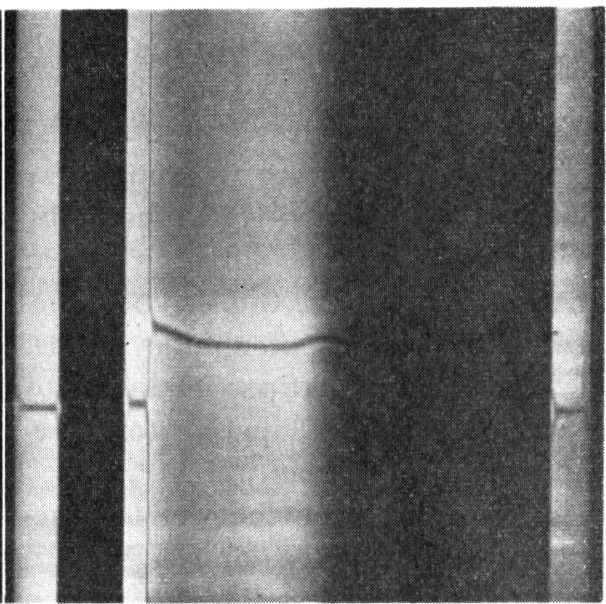

FIG. 6. Sedimentation Pattern of A 280 Substance $(0.25 \%)$ in $0.1 \mathrm{M}$ Phosphate Buffer ( $\mathrm{pH}$ 6.0) containing $0.1 \mathrm{M} \mathrm{NaCl}$, in a Synthetic Boundary Cell at 59,780 r.p.m., Temperature, $20.0^{\circ} \mathrm{C}$.

* Various bioassays including antibacterial, antiHeLa cell and antitumor activitics were carried out by the methods described in thr preceding paper ${ }^{5}$ ).
8) J.T. Edsall, "The Proteins", Vol. 1, Academic Press, 1953, p. 634. 9) H.G. Elias, Angew. Chem., 73, 209 (1961). 
tate $(80 \mathrm{~g})$ was dissolved in dilute $\mathrm{HCl}$ at $\mathrm{pH} 2.0$ and the solution was dialysed against a large amount of $0.02 \mathrm{~N} \mathrm{HCl}$ at $4^{\circ} \mathrm{C}$, through a Visking cellophane tube. The dialysed solution in the tube was clarified by centrifugation and concentrated by freeze-drying. The active component (17 g, in vivo minimum effective dose, $350 \mu \mathrm{g} /$ mouse/day) was recovered from the concentrated solution by addition of EtOH (2.0 1). The dried active powder (10.6 g) was dissolved in water $(200 \mathrm{ml}, \mathrm{pH} 2.0)$ and purified by re-precipitation with EtOH at $4{ }^{\circ} \mathrm{C}$ (the precipitate between $40 \sim 75 \% \mathrm{v} / \mathrm{v}$ EtOH was collected; yield, $60 \%$ ), then by passing through a short column of DEAE-cellulose. The filtrate was applied to a CM-cellulose column (approximately $20 \mathrm{~g}$ of dry powder), equilibrated with $0.05 \mathrm{M} \mathrm{NaH} \mathrm{PO}_{4}$ at $\mathrm{pH} 4.5$ at $4^{\circ} \mathrm{C}$. The column was eluted first with a $1: 1$ mixture of $1.0 \mathrm{M}$ $\mathrm{NaCl}$ and $0.10 \mathrm{M} \mathrm{NaH} \mathrm{PO}_{4}$, then with a $1: 1$ mixture of $2.0 \mathrm{M} \mathrm{NaCl}$ and $0.10 \mathrm{M} \mathrm{NaH} \mathrm{PO}_{4}$; the remaining materials in the column were eluted with $0.04 \mathrm{~N} \mathrm{HCl}$. After dialysis, each fraction was lyophilized, and tested for the activity against Ehrlich ascites carcinoma in mice, ultraviolet and infrared absorption of each fraction were measured. Most of the antitumor activity was found in the eluate having $\mathrm{NaCl}$ concentration of $0.5 \mathrm{M}$ (yield, $1.2 \mathrm{~g}$ : in vivo minimum effective dose, $50 \mu \mathrm{g} /$ mouse/day) .

Eight hundred milligrams of $0.5 \mathrm{M} \mathrm{NaCl}$ eluate, when examined by gel filtration of Sephadex G-50 showed two distribution maxima $\left(K_{\mathrm{D}}, 0.10\right.$ and 0.82 , developed with distilled water), was re-chromatographed on a column of CM-cellulose (15 g) employing elution with a number of stepwise increase in $\mathrm{NaCl}$ concentration from $0.04 \mathrm{M}$ to $0.6 \mathrm{M}$. Seventy tubes were collected, each having $8 \mathrm{ml}$ of effluent. The protein content of each tube was determined by measurement of light absorption at $280 \mathrm{~m} \mu$, and the bioactivity by bioassay in vivo as before. The effluent diagram is shown in Fig. 7 and A216 was found to appear in narrow zones, corresponding to $0.3 \sim 0.4 \mathrm{M}$ $\mathrm{NaCl}$ effluents. After dialysis the active fraction was lyophilized to yield A216 preparation (259 mg; nitrogen content, $12.6 \%$ ) with activity ten times of the starting material. When examined by gel filtration of Sephadex G-50, the purified preparation showed essentially a single peak $\left(K_{\mathrm{D}}, 0.86\right.$, developed with distilled water). Further purification by the third chromatography on CM-cellulose was unsuccessful.

Isolation of A 280 Substance.

The isolation and purification of A280 were followed by in vitro antiHeLa cell activity, in parallel with in vivo antitumor activity.

After extraction of quinoxaline antibiotics with ethyl acetate, the remaining A280 broth was freezedried, and the black residue ( $16 \mathrm{~g})$ was treated with $\mathrm{MeOH}(250 \mathrm{ml})$ at $5^{\circ} \mathrm{C}$. The $\mathrm{MeOH}$ insoluble material $(10 \mathrm{~g})$ was dissolved in water $(200 \mathrm{ml})$, and the solution was then dialysed against cold water for

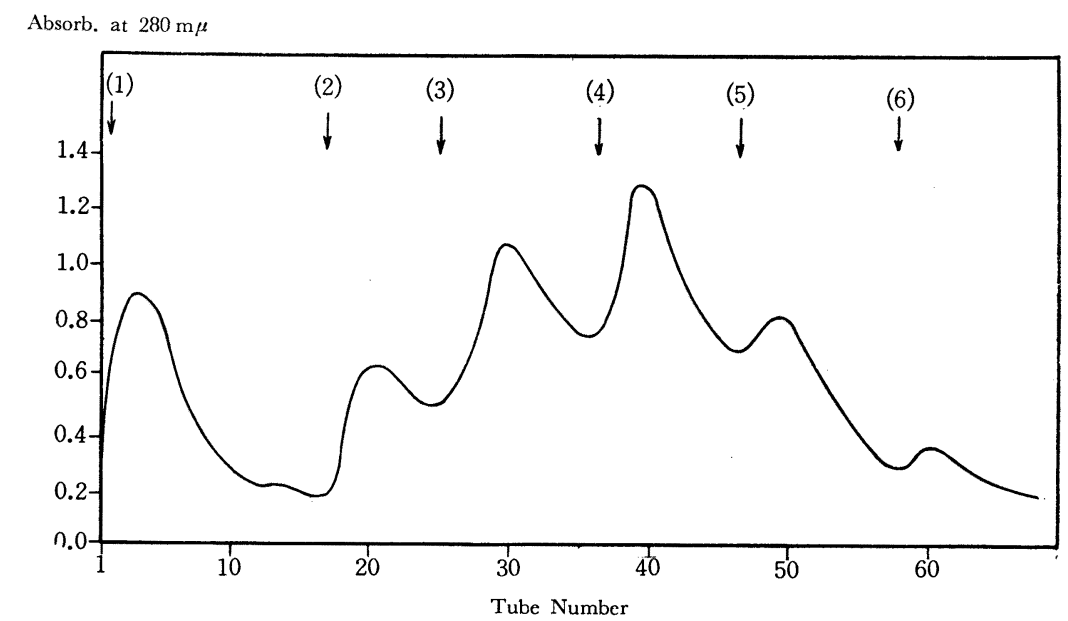

FIG. 7. Chromatography of Crude A 216 Substance on CM-Cellulose.

$\begin{array}{llll}\text { 1. } 0.05 \mathrm{M} \text { phos. } & \text { 2. } 0.1 \mathrm{M} \mathrm{NaCl}-0.05 \mathrm{M} \text { phos. } & \text { 3. } 0.2 \mathrm{M} \mathrm{NaCl}-0.05 \mathrm{M} \text { phos. } & 4.0 .3 \mathrm{M} \mathrm{NaCl}-0.05 \mathrm{M} \text { phos. } \\ \text { 5. } 0.4 \mathrm{M} \mathrm{NaCl}-0.05 \mathrm{M} \text { phos. } & 6.0 .6 \mathrm{M} \mathrm{NaCl}-0.05 \text { phos. }\end{array}$ 
48 hours using a Visking cellophane tube. The crude A280 (2.0 g; in vivo minimum effective dose, $50 \mu \mathrm{g} /$ mouse/day; in vitro minimum effective concentration, $10 \mu \mathrm{g} / \mathrm{ml}$ ) was obtained from the inner solution of dialysis by freeze-drying.

Later, the crude A280 (4.8 g; in vivo minimum effective dose, $50 \mu \mathrm{g} /$ mouse/day) was directly prepared from the precipitate resulting from the saturation of broth filtrate $\left(\begin{array}{ll}8 & 1\end{array}\right)$ with ammonium sulfate at $\mathrm{pH} 6.0$, followed by dialysis, freeze-drying and $\mathrm{MeOH}$ fractionation.

Two hundred and seventy milligrams of the crude A280 preparation was dissolved in $7 \mathrm{ml}$ of $0.01 \mathrm{M}$ sodium phosphate buffer at pH 6.0 and passed through a short column $(2.5 \times 6 \mathrm{~cm})$ of $\mathrm{CM}$-cellulose and then applied to a $2.5 \times 30 \mathrm{~cm}$ column of DEAE-cellulose at a temperature of $4^{\circ} \mathrm{C}$. This was eluted successively with $0.05 \mathrm{M}$ sodium phosphate buffer ( $\mathrm{pH} 6.0$ ) containing $\mathrm{NaCl}$ of increasing concentration, and $8 \mathrm{ml}$ fractions of effluent were collected (Fig. 8). The first two fractions eluted with $200 \mathrm{ml}$ of phosphate buffer and $200 \mathrm{ml}$ of phosphate buffer containing $0.1 \mathrm{M}$ $\mathrm{NaCl}$, gave no ultraviolet absorption and no antitumor activity, and showed infrared absorption spectra similar to that of typical carbohydrate. The next fractions eluted with phosphate buffer containing $0.3 \sim 1.0 \mathrm{M} \mathrm{NaCl}$, gave ultraviolet absorption and showed infrared absorption spectra similar to that of glycoprotein, and both in vivo and in vitro maximum activities were shown by the second "protein peak" which was eluted by phosphate buffer containing $0.5 \mathrm{~m}$ NaCl. The active fractions were pooled, and the combined solution was desalted by dialysis and subjected to re-chromatography on DEAE-cellulose, eluting with more subdivided increasing $\mathrm{NaCl}$ concentration. Analysis of the effluent revealed that A280 came off the column with phosphate buffer containing $0.45 \mathrm{M} \mathrm{NaCl}$ as eluate. By passing through a column of Sephadex G-75 followed by lyophilization, about $40 \mathrm{mg}$ of desalted A280 preparation (nitrogen content, $11.2 \%$; in vivo minimum effective dose, $5 \mu \mathrm{g} /$ mouse/day; in vitro minimum effective concentration, less than $1 \mu \mathrm{g} / \mathrm{ml}$ ) was recovered from the active filtrate.

\section{Gel Filtration of Protein.}

The filtration experiments were made at room temperature $\left(25 \sim 35^{\circ} \mathrm{C}\right)$ with three columns (each ca. $2.5 \times 26 \mathrm{~cm}$ ) each packed with about $100 \mathrm{ml}$ of the cross-linked polysaccharide Sephadex G-25, G-50 and G-75 swollen in water. After equilibration of the columns with distilled water or with $0.05 \mathrm{M}$ sodium phosphate buffer at $\mathrm{pH} 6.0$, five to fifteen milligrams of the proteins to be tested were dissolved in $5 \mathrm{ml}$ of $0.05 \mathrm{M}$ phosphate buffer at $\mathrm{pH} 6.0$ and put on the columns. Elution was then started with the same aqueous solution as was used for equilibration

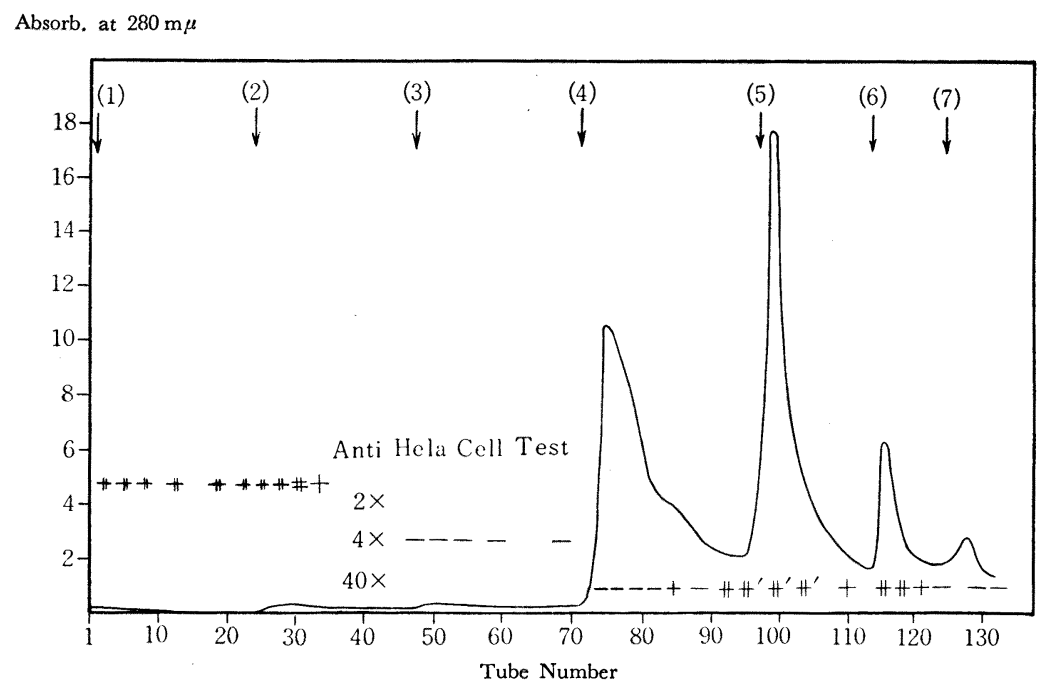

FIG. 8. Chromatography of Crude A 280 Substance on DEAE-Cellulose.

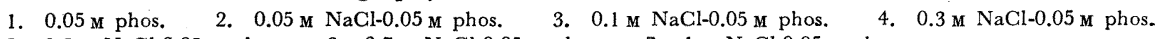

5. $0.5 \mathrm{M} \mathrm{NaCl}-0.05 \mathrm{M}$ phos. $6.0 .7 \mathrm{M} \mathrm{NaCl}-0.05 \mathrm{~m}$ phos. $7.1 \mathrm{M} \mathrm{NaCl}-0.05 \mathrm{M}$ phos. 
with the flow rate of $1 \sim 5 \mathrm{ml}$ per min. The effluent was collected in fractions of $5 \mathrm{ml}$ and analysed by measurement of the optical absorption of a protein at a suitable wavelength.

$K_{\text {D }}$ Value was calculated by the following equation:

$$
K_{D}=\frac{V-V_{0}}{V_{i}}
$$

where, $V:$ elution volume for tested protein.

$V_{0}$ : external volume of water (experimentally determined as the elution volume for albumin or $\gamma$-globulin).

$V_{i}:$ inner volume of water $\left(=V_{t}-V_{0}-V_{g}\right)$.

$V_{g}$ : volume of air-dried gel.

$V_{t}:$ total volume of swollen gel.
Acknowledgement. The author wishes to express his hearty thanks to Dr. H. Ogawa and Dr. Y. Sekizawa of this laboratory for their kind guidance and encouragement throughout the work. He is also indebted to The Tokyo Industrial Research Institute and to The Institute of Physical and Chemical Research for ultracentrifugal data, and to the members of Pharmaceutical Division, Kawasaki Factory of this Company, for various bioassays and for providing culture broths. The technical assistance of Miss $\mathrm{S}$. Ueno is also acknowledged. 